\title{
Puertas adentro de la calle. Fotografía participativa y derecho de mirada en Santiago
}

\author{
Doors Inside the Street. Photovoice and Right \\ of View in Santiago
}

\author{
Carla Pinochet Cobos y Leonardo Piña Cabrera \\ Universidad Alberto Hurtado, Santiago, Chile \\ cpinochet@uahurtado.cl / Ipina@uahurtado.cl
}

\section{Resumen}

Sobre la base de una serie de fotografías y testimonios producidos por un conjunto de personas en situación de calle de la ciudad de Santiago de Chile, el artículo busca reflexionar acerca de las dimensiones epistemológicas, metodológicas y éticas involucradas en la producción de estas imágenes en tanto dispositivos de representación de un otro subalterno. Analizando sus posibilidades como mecanismos de restitución de un derecho de mirada, este trabajo intenta distanciarse de los sesgos miserabilistas y de espectacularización de la pobreza que han predominado en las aproximaciones al fenómeno de la situación de calle, desafiando los supuestos y perspectivas dominocéntricos y domiciliocéntricos que pesan sobre sus autores, por una parte, y discutir la autoridad etnográfica que de todas formas carga consigo la persona del investigador, por la otra.

Palabras clave: situación de calle, fotografía participativa, derecho de mirada, contravisualidad, domiciliocentrismo.

\begin{abstract}
Based on a series of photographies and testimonies produced by homeless people living in Santiago, Chile, this paper aims to reflect on the epistemological, ethical and methodological issues regarding the production of those images when considered as representation devices for a subaltern otherness. By analyzing their possibilities as mechanism for the restitution of the "Right to a point of view", this work tries to take distance from the hegemonic approaches of misery and spectacularizing as lens for analyzing poverty and thus defying "dominocentric" and "home centric" perspectives that are carried by authors, on the one hand, and so discussing ethnographic authority and the epistemic charge of the researcher persona, on the other.
\end{abstract}

Keywords: homelessness, photovoice, right to look, countervisualities, housing centered. 
Cuando uno observa observar, ¡¿Qué observa!?

Juan Luis Martínez

\section{Introducción}

Sobre la base de un conjunto de materiales fotográficos de tipo analógico producidos por una muestra no representativa de personas en situación de calle de la ciudad de Santiago, Chile, este artículo reflexiona acerca de las herramientas visuales y participativas como dispositivos que tensionan la manera tradicional en que se investiga, $y$ luego comprende, este fenómeno. Para tal efecto, sitúa el debate en torno al derecho a la mirada y la posibilidad, ética y epistemológica, de avanzar más allá de una fotografía de la miseria o de la espectacularización de la carencia. En el proceso, discute de qué modo se hace frente a los desafíos representacionales propios del tránsito entre la captura de la imagen y su puesta en circulación como artículo o producto autorizado, en este caso a partir de una segunda discusión relativa a la autoría de tales materiales. ¿Puede la imagen ofrecer una vía de acceso a una población que ha sido históricamente negada e invisibilizada? ¿Puede su puesta en relieve, a partir de una doble consideración visual y testimonial, desandar las muchas páginas escritas y no escritas en torno a dicha omisión? A partir de las nociones de visualidad y derecho de mirada como claves de lectura (Mirzoeff 31-32), este texto busca examinar las dimensiones epistemológicas, metodológicas y éticas involucradas en la producción de este tipo de imágenes, valiéndose para ello de una experiencia de investigación llevada a cabo en Santiago de Chile, durante los años 2015 y $2016 .{ }^{1}$

Nutriéndose de información producida a través de la entrevista en profundidad y la fotografía participativa, pero también del análisis y curatoría compartida de las imágenes con los sujetos que participaron del estudio, este artículo y la investigación de que deriva se incorpora a una breve pero intensa lista de estudios similares. Con diferente acento y logro en su esfuerzo, pero intentando trascender de una antropología sin el otro, tales aportes han puesto en juego la centralidad del especialista en el acto de observar, ya sea democratizando el instrumental técnico de registro y vaciando su resultado en la forma de documento audiovisual (Arce et al.) o textual propiamente dicho (Grinschpun y Bendersky 7-9), o bien utilizando dicha cesión como fuente de indagación y comprensión específica: en el caso de Radley, Hodgetts y Cullen, para entender las formas en que la gente en esta situación hace frente a

1 Aunque solo se abordará la experiencia de investigación realizada en Santiago, la información aquí aludida pertenece a un proyecto de mayor alcance, que incluyó dos ciudades chilenas y dos ciudades uruguayas: "Pupilas vacías, o el acto de observar puertas adentro de la calle. Un estudio comparativo de fotografía participativa, representaciones sociales y situación de calle" (FONDECYT de iniciación 11140871). 
la vulnerabilidad y se reconoce en ella (274-75); en el de Miller, como mecanismo de autoafirmación a partir de la identificación del sentido que a través de su experiencia y la imagen adquiere (122); en el de Bermúdez, a fin de conocer los procesos de reconstrucción de la identidad masculina en el contexto de la calle (12-14); y en el de Arcos, para avanzar en el conocimiento y representación de sus cotidianos y trayectorias de vida (54-80).

Reaccionando, pues, al modo predominante en que se ha abordado el fenómeno, es decir a su mayoritaria comprensión como distintas formas de desafiliación - retraimiento, asocialización o conducta desviada en Merton (76), o falta de lazo o disminución de este en Bahr (17) —, este artículo plantea la necesidad de reconocer aquello que el excesivo énfasis en la carencia y la miserabilización no han permitido apreciar. Resultado del no reconocimiento de su ocupación y tenencia de posición, este trabajo comparte la crítica a los estudios del sinhogarismo y al predominio de la mirada cuantitativa (Bachiller 10), buscando avanzar en otras maneras de abordar el fenómeno, no ya a partir de las carencias - materiales, sociales y simbólicas - que le caracterizarían. De este modo, el estudio en el que este texto se enmarca intenta prestar atención a aquello que ocurre durante la situación de calle, eso que por oposición podría consignarse como vagabundancias y que trascendería de la pregunta por el quiebre con y sin techo, las privaciones o la aislación social en que se ha insistido.

Con el propósito de registrar las formas de habitar la calle desde la perspectiva de uno de sus actores menos considerados, este estudio desarrolló una metodología basada en la fotografía participativa, o fotovoz, como dispositivo que tensiona la autoridad etnográfica y propicia la reflexividad (Rabadán y Contreras 148). Con ello se pretendió, al compartir el instrumento mediante el cual se retrata la realidad, que el análisis pudiera avanzar en el efectivo abordaje de las elaboraciones culturales de quienes viven esta situación, reconociendo, como ha dicho Romaní (305), la configuración retórica de los fenómenos de la marginación desde distintos niveles. Y que, por la desigual atención que se les presta, incluso terminan proyectándose unas sobre otras como fuente de caracterización que propiciaría - como en el caso de la prensa relativa a este fenómeno-, no solo una preocupación estacionaria del mismo sino una representación desacreditante que coadyuva a la mantención de relaciones sociales desiguales (Hodgetts et al. 497-98).

Así, mediante la entrega de cámaras desechables de 27 tiros cada una a las personas en situación de calle que decidieron colaborar con esta investigación, 48 en total, ${ }^{2}$ se obtuvo un conjunto de imágenes referentes al universo, material y

2 Desglosada esta cantidad, dígase que se trabajó con 14 mujeres y 34 hombres, sobrerrepresentándose la población de mujeres que en ambos países fluctúa en torno al $16 \%$ de quienes viven en situación de calle. Respecto a sus edades, la totalidad fue población adulta, concentrándose en los tramos etarios 30-39 (14 entrevistados), 40-49 (12) y 50-59 (12). La mayoría de nacionalidad chilena (28) y uruguaya (15), también hubo presencia peruana (2), colombiana (1), ecuatoriana (1) y argentina (1), el grueso de los cuales señaló tener estudios secundarios (22) y primarios (15), sea completos o incompletos. 
simbólico, de esta población: su habitar, su cotidianidad y sus desplazamientos por la ciudad, entre otros. Con posterioridad, al reencontrarse fotógrafo e investigador, se les solicitó a los autores de las imágenes que dieran cuenta de su sentido e intención. Como bien nota Melleiro y Gualda (56), no solo la imagen capturada condensa información de interés para la investigación social, sino también todo el proceso reflexivo que atraviesa su producción: la selección de escenas y la construcción de sentido en torno a ellas ofrece un espacio/tiempo propicio para la representación de la realidad vivida, posibilitando una abertura de emociones e ideas que son percibidas y compartidas, primero, de manera espontánea, al seleccionar la escena; luego, en un proceso de racionalización, al analizarlas de acuerdo a Vaisman (citado en Melleiro y Gualda 52).

El presente artículo inicia situando la problemática en la pregunta por el reconocimiento del sujeto subalterno en tanto alteridad. Revisando los aportes de diversos autores que han examinado esta tensión constitutiva entre dominación y otredad, nuestra discusión pone de relieve la dimensión sensible de todo orden sociopolítico, con especial énfasis en la visualidad. De esta manera, proyectando con Rancière y Mirzoeff la potencia de una contravisualidad a los estudios de la situación de calle, se entregan algunas claves conceptuales para pensar estos derechos de mirada que soslayan el dominocentrismo que ha marcado el estudio de este tipo de poblaciones. En el siguiente apartado, la reflexión se mueve hacia una pregunta por el estatuto ético de la fotografía de la miseria. Examinando el dispositivo fotográfico en tanto régimen visual marcado por un campo de tensiones en el que imagen y acción parecen enfrentarse, se da cuenta de algunos alcances políticos de la representación del otro y los muchos peligros - miserabilismo, espectacularización- que la circundan. Posteriormente, se interroga la posibilidad de levantar una voz —o, en este caso, una imagen- dentro de la subalternidad; luego de lo cual se vuelve sobre el proyecto en que se enmarca esta artículo, revisándose algunas cuestiones de carácter metodológico, ético y epistemológico del mismo, para presentar y discutir una breve selección de imágenes que permiten disputar el lugar protagónico de la miseria en la comprensión de la situación de calle, tal vez abriendo paso a fragmentos contravisuales que restituyen el derecho de mirada de quienes han sido concebidos como meros sujetos de despojo y de carencia.

\section{Derecho de mirada. Contravisualidades desde la otredad subalterna}

Desde los inicios de la antropología hasta sus expresiones más contemporáneas, la pregunta por la otredad ha sido una inquietud de largo aliento en la disciplina. Considerada por algunos como uno de los principales criterios que distinguen las producciones antropológicas de otras perspectivas disciplinares, dicha interrogante 
ha iluminado los más diversos ámbitos temáticos y se han ensayado todo tipo de metodologías para sondear tentativas de aproximación a la diferencia. Ciertamente, los otros que imaginó la antropología clásica se han multiplicado y complejizado con el paso de las décadas, y las formas de la alteridad que caracterizan nuestros tiempos son tal vez menos nítidas y estables que las que analizaron los manuales de antropología del siglo xx. Las fronteras históricas de aquella alteridad se han disuelto progresivamente, de modo que la investigación antropológica ya no puede contentarse con apelar a comunidades autocontenidas ni esencias incontaminadas. La pregunta por el otro, entonces, se ha visto actualizada en su tránsito por los escenarios urbanos, transnacionales, globalizados, e incluso virtuales de la contemporaneidad.

Este interés por las formas de pensar y significar el mundo que escapan al orden hegemónico encuentra un segundo desafío conceptual y epistemológico al lidiar, además de la diferencia, con la desigualdad que en no pocas ocasiones la cruza. Los sujetos que habitan los márgenes de la sociedad configuran, de este modo, un particular paisaje de otredad que ha sido reducido en innumerables ocasiones a su mera carencia, vale decir, a la escasez de recursos materiales, sociales y/o simbólicos que les caracterizaría. Imaginando rutas alternativas, algunos autores han hecho el ejercicio de visualizar los alcances que supondría aplicar el método relativista —-desarrollado por la antropología - en un territorio tradicionalmente sociológico: la cultura popular. Así, en un texto escrito a dos voces, Grignon y Passeron (95) examinaron la posibilidad de aproximarse a la cultura popular bajo esta clave de otredad, poniendo en tensión dos perspectivas antagónicas: por una parte, aquella que arranca del supuesto de que, como toda cultura, la cultura popular tiende a organizarse como un sistema simbólico coherente y con cierto nivel de autonomía; por la otra, la constatación innegable de que dicho sistema cultural se encuentra atravesado por una condición de dominación, y que por ende sus valores y prácticas no serían independientes de aquella constitución subordinada. De acuerdo a ello, esta alteridad mezclada que caracterizaría a la cultura de los sectores populares confronta, en consecuencia, dos desafíos analíticos de peso: primero, una vez franqueadas las inercias del dominocentrismo - el cual asumiría, irreflexivamente, la superioridad de la cultura dominante-, todavía quedaría hacer frente a un segundo desafío, el dominomorfismo - es decir, al problema de no disponer de más categorías para pensar al sujeto popular que las de la cultura legítima-.

Desde otra vereda, esta vez a partir de la trinchera disciplinaria de la filosofía y los estudios culturales, el texto capital de Spivak formula la encrucijada que supone el diferendo del sujeto subordinado. La recordada pregunta que da nombre a su artículo remite al silenciamiento estructural que experimentan los dominados: “¿Puede realmente hablar el individuo subalterno haciendo emerger su voz desde la otra orilla, inmerso en la división internacional del trabajo promovida en la sociedad capitalista, dentro y fuera del circuito de la violencia epistémica de una legislación imperialista y de programa educativo que viene a complementar un texto más temprano?" (Spivak 15). 
En su análisis de las estrategias críticas de los investigadores que orbitan la corriente poscolonial, Spivak elogia, y a la vez se distancia de, aquellas operaciones con las que se ha propuesto dar voz a los invisibilizados. Dichas críticas, señala, se valen de las herramientas que el mismo discurso colonizador provee, puesto que operan sobre la base de una catacresis fundacional, de la cual no es posible escapar sino - como apunta Derrida, citado en el mencionado texto- "reproduciendo como delirante la voz interior que es la voz del otro en nosotros". Ese habla del sujeto subalterno no sería más que un fenómeno físico, pues no logra adquirir un estatus dialógico, una posición discursiva que resulte socialmente legible.

A la luz de estas reflexiones, este trabajo plantea que el reconocimiento del subalterno como una otredad - y no solo como un efecto de la desigualdad o la dominación- constituye una operación antropológica fundamental. Observar al otro en esta clave, suspendiendo la vigencia del propio juicio para escuchar los signos de aquello que se resiste a la decodificación, constituye un mecanismo vital para una antropología capaz de internarse en los dilemas de la cultura popular y de los sujetos marginados. Por ello, un proyecto de esta índole depende antes de los sentidos que de la intelección, pues no se trata de ordenar la realidad en categorías preestablecidas, sino de prestar atención a sus emergencias perturbadoras. El aparato conceptual desarrollado por Rancière ofrece un marco esclarecedor para comprender esta prevalencia. En sus aproximaciones a la política, acontecimiento más extraño e infrecuente de lo que usualmente se asume, el autor francés desarrolla la noción de "división de lo sensible" para dar cuenta de aquel "reparto de partes y lugares" que descansa en una "división de los espacios, los tiempos y las formas de actividad que determina la manera misma en que un común se presta a participación, y unos y otros participan en dicha división" (Rancière, La división 15). La política tiene lugar solo en la medida en que se produce un quiebre en dicho reparto de lo sensible, que reconfigura los espacios y lugares asignados a cada cual ante la emergencia de los que no tienen parte (Rancière, El desacuerdo 60). El lenguaje y su capacidad de poner en común lo justo y lo injusto es un punto crucial para el despliegue de lo político, que permite dirimir quién posee el lenguaje y quién solamente el grito: "La política consiste - asevera Rancière- en reconfigurar la división de lo sensible, en introducir sujetos y objetos nuevos, en hacer visible aquello que no lo era, en escuchar como a seres dotados de palabra a aquellos que no eran considerados más que como animales ruidosos" (Sobre políticas 19). Cuando aquellos que no hablan demuestran que pueden emitir un lenguaje inteligible y lo hacen contar, se instituye una comunidad (política) basada precisamente en ese desacuerdo fundamental.

Este lenguaje subalterno en busca de una nueva posición de enunciación no se restringe al ámbito de la palabra y la voz. Amparándose en los postulados de Rancière, Mirzoeff ha apuntado que también en el derecho a mirar se pone en juego un reconocimiento de la otredad. El derecho de mirada, para este autor, se contrapone a la existencia de una visualidad en tanto orden prefigurado desde la autoridad. La 
visualidad consistiría en un fenómeno de orden imaginario, antes que propiamente perceptual, en la medida en que "engloba un conjunto de relaciones en las que se combinan la información, la imaginación y la reflexión para generar un panorama tanto físico como psíquico" (34). Valiéndose de un conjunto de operaciones sucesivas - nombrar y clasificar lo visible; escindir y segregar a los visibilizados; legitimar y naturalizar dicho orden estético- - un complejo de visualidad es siempre una ordenación de los procesos históricos de modo que resulten perceptibles para la autoridad, afirma Mirzoeff. En ese marco, el derecho a mirar no es otra cosa que un reclamo de autonomía frente a un orden perceptual impuesto; es un derecho que se rebela frente a una autoridad que elabora "su propia interpretación de lo sensible con el objetivo de generar espacios de dominación, primero mediante leyes y posteriormente a través de la práctica estética" (35).

No es casualidad que la antropología haya ocupado un lugar protagónico en la configuración del complejo de visualidad imperial, el segundo de los tres que desarrolla Mirzoeff. En tanto disciplina diseñada para lidiar con la otredad, los postulados de los primeros antropólogos se encargaron de materializar las operaciones necesarias para construir un régimen perceptual jerarquizado de acuerdo a los valores e intereses de Occidente. El célebre concepto de cultura de Tylor permitió identificar los sujetos primitivos como seres culturales, pero a la vez consignó su existencia a una subordinación natural inscrita en la jerarquía civilizatoria (19). De esta manera, las tesis evolucionistas superpusieron estas asimetrías culturales a una dimensión espacial, dando lugar a un régimen de visualidad que asimila proximidad y civilización. Más aún, como sostiene Fabian, en esta operación se instaura una "política del Tiempo" proyectada sobre el Espacio, que establecía un correlato entre la secuencia histórica y la posición geopolítica: al asignar al desarrollo evolutivo (salvajismo/barbarie/civilización) una correspondencia espacial, "el 'alli’ se convirtió en 'entonces', y lo más remoto se convirtió en lo más primitivo" (Foster 181).

También las otredades constituidas en el interior de las sociedades se han visto inscritas en un régimen de visualidad regulado por la administración dominante. En diversos puntos del globo, la historia de desplazamientos y relocalizaciones de los sectores populares en las ciudades ha respondido al interés de las clases dominantes por empujar la pobreza fuera del campo de visibilidad de la vida urbana. En América Latina, y en particular en la ciudad que aborda este artículo, esta política de segregación se vio intensificada con las dictaduras militares de la segunda mitad del siglo xx. La ciudad de Santiago constituye un ejemplo paradigmático en este sentido: a fines de los años setenta, en el marco de la dictadura de Pinochet, se lleva a cabo una política de corte neoliberal que transforma radicalmente la localización socio-espacial de los sectores urbano-marginales (Morales y Rojas 1). El traslado masivo de habitantes de campamentos hacia nuevas localizaciones empuja a los pobres hacia comunas periféricas, polarizando la diferencia entre comunas ricas y comunas pobres. Esta reconfiguración espacial de los cuerpos en el territorio urbano de la capital instala 
un orden ético y estético que terminará por naturalizarse, asentando una particular repartición de aquello que resulta visible, audible, perceptible.

Concordante con ello, en el ámbito de la situación de calle la política oficial y la respuesta de la ciudadanía ha movilizado diversas medidas para administrar la visualidad urbana, evitando la circulación pública de las personas sin hogar y llamar al confinamiento de estas en albergues inaccesibles a la mirada pública, so pretexto de asegurar su protección. El caso del programa de Desocupación de los espacios públicos de la Intendencia de Montevideo, por ejemplo, es ilustrativo de ello; lo mismo que la Ley de Faltas en Uruguay al penalizar, entre otras cosas, la pernoctación en la vía pública (Camejo et al. 3). No lo único, el actuar de la Dirección General de Control Urbano, en la ciudad de Rosario, también es representativo de tal proceder al restringir, irónicamente, el derecho a la ciudad a esta población, no obstante el nombre de su campaña, Rosario inclusiva pudiera sugerir otra cosa (Bufarini 73). En nuestro país, destaca en este sentido la reacción que hacia 2008 suscitó la ocupación por parte de esta población del llamado pueblito Melipulli en la ciudad de Puerto Montt (Piña 508-553); o la actuación de programas como Rescate Social, de la Municipalidad de Santiago, tristemente célebre por el encierro contra voluntad del recientemente fallecido Divino Anticristo (Marcazzolo 6). El derecho a mirar - sostiene Mirzoeff - se encuentra estrechamente vinculado con el derecho a ser visto (45). La posibilidad de una contravisualidad, en esta medida, alberga la promesa de pensar otros modos de percibir la realidad y reorganizar las categorías que, en determinado complejo de visualidad, aparecen como naturales. Se trata, pues, de una nueva clase de realismo que disputa las representaciones hegemónicas denunciándolas, precisamente, como construcciones arbitrarias. Si las personas en situación de calle han sido construidas en el discurso público a partir de su conferida condición de despojo, el ejercicio de autorrepresentación visual que se propone puede ofrecer herramientas para la emergencia de una contravisualidad que aspire a disolver los contornos imperantes de lo sensible. Sin embargo, convendría avanzar con cautela o cierta moderación en tal pretensión.

En esta investigación, la fotografía participativa entrega a un conjunto de personas los recursos materiales y técnicos para producir imágenes sobre sus universos cotidianos. Siendo aún más precisos, no se trata de la entrega de una herramienta ajena, sino de una solicitud particular de movilizar recursos que les resultan familiares, esta vez con un propósito externo (la investigación): casi todos los participantes del estudio conocen de cerca las cámaras fotográficas, las han usado en más de una oportunidad y hasta disponen de una cotidianamente en su teléfono celular (Rice et al. 693; Buente y Quiroga). Las imágenes resultantes tienen, en este sentido, la potencia de otorgar visibilidad o dislocar la posición histórica de estos cuerpos y objetos subalternos. No obstante ello, estas auspiciosas proyecciones políticas no se encuentran liberadas de la discusión epistemológica que Grignon y Passeron resumieron bajo el concepto de dominomorfismo, y que Spivak examinó como un problema de lenguaje. De qué manera 
se manifiesta "la voz del otro en nosotros", sigue siendo una pregunta vigente. Incluso si consideramos que la producción de imágenes proporciona un soporte con menos trabas - más accesible - que la escritura, ¿hasta qué punto puede el subalterno «hablar» si solo dispone para ello de unos medios técnicos más o menos ajenos, además de finitos y administrados por quienes los entregan?, ¿ puede la sola pretensión dialógica u horizontalista salvar las muchas páginas de imposición dominocéntrica, dominomorfista y, en este caso, también domiciliocéntrica? Esta constelación de preguntas, lejos de invalidar el ejercicio aquí presentado, tiene el propósito de poner distancia respecto de fórmulas instantáneas, mesiánicas o clausuradas. Una antropología de la imagen, constituida en torno al problema del otro, exige preguntarse por los alcances epistemológicos, conceptuales y metodológicos de la producción visual. Y cuando ese otro corresponde, además, al que "no tiene parte", resulta necesario interrogarse también por una dimensión que ha sido relegada en demasiadas ocasiones: el estatuto ético de la fotografía de la miseria.

\section{En torno al estatuto ético de la fotografía de la miseria}

Las imágenes del horror suelen venir acompañadas de las buenas intenciones que las hicieron posibles. Detrás de las innumerables imágenes de guerras, genocidios, hambrunas, masacres y catástrofes que han pasado frente a nuestros ojos, hay también innumerables tentativas de denuncia del sufrimiento y el abuso, o de visibilización de las víctimas y los oprimidos. A lo largo del convulsionado siglo xx, señala Sontag, muchas personas se empeñaron en creer "que si el horror podía hacerse lo bastante vívido, la mayoría de la gente entendería que la guerra es una atrocidad, una insensatez" (22-23). No obstante ello, la guerra no ha dejado de volver, y con ella el dolor de lo inenarrable. Las posibilidades técnicas que ofrece la fotografía ocupan un papel clave en esta historia: su capacidad de representación visual de lo instantáneo le otorgó un estatus de vehículo privilegiado de la realidad objetiva, haciéndola portadora natural de la misión de sensibilizar a los indemnes. Todavía hoy, en tiempos donde la información es infinita, "la fotografía ofrece un modo expedito de comprender algo y un medio compacto de memorizarlo" (Sontag 31). Su accesibilidad y replicabilidad, por cierto, constituyeron elementos centrales para el desarrollo de una política de visibilización de la miseria humana. Inscrita en un régimen de realidad que la posiciona en proximidad íntima con los hechos mismos, la fotografía se convirtió, así, en el soporte-testimonio por excelencia: el más fiable, masivo y susceptible de ser retenido en la memoria.

Diversos análisis han deconstruido este régimen de autenticidad de la fotografía, subrayando las dimensiones subjetivas que atraviesan dicha práctica. En el nivel más elemental, es necesario remarcar que las operaciones que hacen posible la imagen fotográfica no son sino un conjunto de decisiones personales del fotógrafo, 
que ponen en cuestión el supuesto de objetividad que se asume como connatural a esta producción de imágenes - “el encuadre es político”- Pero también el fotógrafo está implicado en aquello que su cámara registra, puesto que la operación requiere de una presencia corporeizada y de una posición de observación; "el acto de fotografiar es algo más que observación pasiva”, apunta Sontag (27). Sin embargo, más allá de este punto de partida, no hay consensos seguros. Hay quienes leen esta implicación del fotógrafo en la escena observada como un modo de alentar, aunque sea implícitamente, la continuación de lo que está ocurriendo: "Hacer una fotografía es tener interés en las cosas tal como están, en un statu quo inmutable (al menos por el tiempo que se tarda en conseguir una 'buena' imagen)" (Sontag 28). El grueso de este argumento se encontraba ya contenido en la apelación de Benjamin en "El autor como productor", en donde el autor denuncia la estetización de la tragedia a través de la fotografía y su capacidad de convertir la miseria humana en un objeto de consumo. En el otro extremo, están aquellos que desestiman como falsa la oposición entre fotografía y acción, e insisten en el carácter político de las imágenes: "el éxito de una singular fotografía es otra manera de ocuparse de los niños que se mueren de hambre" (Rancière, "El teatro" 86).

Una breve reseña de las pasiones que desata el trabajo del fotógrafo brasileño Sebastião Salgado puede ilustrar las múltiples posiciones a este respecto. Su trabajo documentando la guerra, la explotación y los éxodos de Latinoamérica y África le han reportado el reconocimiento internacional, a la vez que un sinnúmero de críticas. Mientras desde el primer ángulo se subraya su trabajo humanitario y su compromiso con las comunidades y el medioambiente, desde la otra vereda se califica su producción fotográfica como un "voyeurismo sentimental”; una "iconografía antropofágica”; o una "estetización de la miseria". El trabajo estético que caracteriza las fotografías de Salgado parece atentar, en algún nivel, contra la veracidad de aquellas imágenes en tanto documentos. Estamos habituados a identificar la belleza con el fotograma, explica Sontag; y el fotograma, con la ficción (citado en Espada). La cuidada composición de sus fotografías, entonces, pareciera desviar la atención de la tragedia retratada; y peor aún, solo consigue convocar la pasividad anestesiada de los espectadores. "La belleza es una llamada a la contemplación, y no a la acción”, afirmaba la crítica Ingrid Sischy sobre Salgado, para el New Yorker (citado en Levi-Strauss 50).

La interpelación ética a este tipo de fotografías involucra también consideraciones relativas a la identidad de los representados - ¿qué lugar ocupan en ellas los nombres propios, las historias singulares? - ; al derecho a la privacidad y la intimidad de las personas - ¿cómo se garantizó el consentimiento de quienes fueron retratados? -; y al derecho a disentir y administrar la propia imagen - ¿qué espacio de negociación respecto del proceso y sus resultados detentaron los protagonistas de las imágenes?-. Es relevante apuntar que, en los desarrollos de la fotografía documental en el Chile contemporáneo, estas preguntas han recibido insuficiente atención. La mayor parte de los textos críticos en torno a la obra de artistas como Paz Errázuriz y Sergio La- 
rraín han optado por elogiar las proezas de dichos fotógrafos, en su vasto registro de los sectores marginales y los submundos delictuales de las urbes locales. En el caso particular de Larraín, quien estuvo detrás de las fotografías de la pobreza de mayor peso en el inconsciente colectivo nacional, resulta sintomática su retirada voluntaria del oficio de fotógrafo. En su fase crepuscular, toma consciencia de que la imagen ya no constituye una fuerza de cambio o transformación, y que sus fotografías de los niños vagabundos no habían logrado hacer nada por ellos (Leiva).

¿Qué puede o debe hacer la imagen por los sujetos que representa? O al menos, ¿qué líneas no debe cruzar en su ejercicio? El manifiesto en torno a la "porno-miseria" que los realizadores colombianos Luis Ospina y Carlos Mayolo presentaron en París junto a la cinta Agarrando Pueblo, establece algunas directrices que bien podrían proyectarse a la práctica fotográfica. Allí dan cuenta del proceso que experimentaba la industria cinematográfica nacional, en cuyas producciones la miseria pasó a constituir una mercancía transable, que operaba como "contrapartida de la opulencia de los consumidores”. Lejos de ofrecer nuevos ángulos de exploración y/o análisis de la pobreza, los autores denuncian en esta operación la emergencia de un cine miserabilista que, a la vez que brinda a los espectadores la posibilidad de "lavar su mala consciencia", termina por convertir "al ser humano en objeto; en instrumento de un discurso ajeno a su propia condición” (Ospina y Mayolo). La noción de "porno-miseria” condensa, en diversos niveles, la problemática ética que ronda la producción y circulación de representaciones visuales en torno a estos otros subalternos que habitan los márgenes sociales. En primer lugar, señala los riesgos que conlleva la espectacularización de la pobreza, la cual se encuentra alimentada por la curiosidad y el morbo que entraña la posibilidad de aproximarse a estos confines de la experiencia humana. En segundo término, presenta un cuestionamiento a los diversos réditos - económicos, políticos y simbólicos - que se pueden obtener de la exhibición pública de la pobreza. Y en tercero, como costo asociado al punto anterior, el concepto de "porno-miseria" permite evidenciar la conversión de los sujetos representados en objetos de consumo, en el marco de un dispositivo de representación que les resulta ajeno y respecto del cual no tienen control alguno.

¿En qué medida las imágenes pueden hacerse cargo de una ética del otro? ¿Cuándo estamos frente a un mero aprovechamiento exhibicionista, y cuándo la imagen despliega la potencia de un proyecto político? En sus reflexiones en torno a la fotografía contemporánea, Régis Durand logra distinguir dos tipos de imágenes: un "documento-grito", que depende exclusivamente del "esto-ha-sido" de un acontecimiento, y un "documento-proyecto", es decir, una construcción elaborada de lo real histórico (citado en Didi-Huberman 41). El dramatismo esteticista de cierta fotografía documental suele apelar al grito, al alarido conmovedor. Para Durand, en cambio, el desafío consiste en preguntarse "cómo la imagen fotográfica puede (aún) servir a un proyecto en particular", trascendiendo la mera estrategia de presentación para fundir el problema ético y el estético en la propia concepción de la obra. 
Asociado a la actividad etnográfica, las figuras que a propósito de la construcción y representación de la realidad levanta Restrepo (83-87) no solo sirven para ilustrar esta discusión, sino para acercarla al terreno antropológico disciplinario. Distinguiendo entre el "etnógrafo asaltante" y el "etnógrafo indiferente", la utilización de la metáfora fotográfica le permite observar la disposición de un artilugio, en este caso la búsqueda de conocimiento, que bien puede actuar como herramienta extractiva o de falsa neutralidad, y que difícilmente se plantea desde la horizontalidad y/o reciprocidad con el otro con quien trabaja. Violentador de su condición agente, tales figuras resumen con fuerza la posición objetivista y naturalista de una fotografía que pasa por alto las realidades que intenta retratar, y que reduce el entendimiento ético a una fase de la actividad y no a todo su proceso.

No existen soluciones instantáneas ni garantías invulnerables respecto del estatuto ético de la fotografía del otro subalterno. ¿Puede la imagen en sí misma devenir un dispositivo político? ¿Pueden sus condiciones de producción ofrecer algo más que la mera representación — siempre parcial y subjetiva - de una realidad? ¿Tiene la imagen la potencia de convertirse en una contravisualidad, que desordene las fronteras vigentes de los cuerpos y las cosas en un nuevo orden perceptible? ¿Cuánto vive una fotografía, más aún en tiempos signados por el predominio de la imagen y su casi instantánea circulación y superación a manos de otra? El ejercicio fotográfico desempeñado aquí por un conjunto de personas en situación de calle busca explorar, precisamente, estas posibilidades performativas. Aun cuando la catecresis fundante que denunciaba Spivak no puede ser franqueada, tal vez estos fotógrafos subalternos - en control de los medios de producción y selección de las imágenes- puedan materializar aquellas experiencias otras sin la necesidad de representarlas. Se revisarán, a continuación, algunos alcances éticos y epistemológicos de esta experiencia de fotografía participativa, proporcionando elementos críticos para avanzar en esta discusión.

\section{Pupilas vacias: una experiencia de fotografía participativa}

Las imágenes producidas en el marco de esta experiencia fotográfica participativa pueden ofrecer algunas claves para soslayar el miserabilismo que ha marcado la concepción del fenómeno. Como se ha esbozado anteriormente, el acento ha estado localizado preferentemente en las carencias, desafiliación y quiebre con y sin techo, prestando escasa atención a aquello que ocurre durante la situación de calle: su cotidianidad, sus vínculos sociales o sus órdenes estéticos, por ejemplo. La procuración de las condiciones de subsistencia pareciera, en este tipo de análisis, negar a esta población la capacidad de cualquier trabajo simbólico más complejo (González 153-154), emergiendo el domicilio, en tanto contexto de la protección social, como el espacio posibilitador del pensamiento y la producción cultural. Tal domiciliocentrismo - que constituiría una rama del etnocentrismo (Piña 49) —, oscurece los universos de significado y de acción 
de las personas en situación de calle. Por el contrario, acá se ha propuesto comprender la situación de calle como un amplio espectro de relaciones, planos y actorías en ningún caso reducible a lo material y a su pura población, observando en los productos de este ejercicio fotográfico la posibilidad de contener una voz otra que no puede ser aprehendida desde las estrechas categorías de la normalidad y la hegemonía.

No obstante ello, tal esfuerzo no está exento del entramado de relaciones de poder que hace posible este y cualquier tipo de investigación. A lo largo de sus desarrollos contemporáneos, el quehacer antropológico ha ido ganando en reflexividad y depurando sus consideraciones éticas, con el objeto de ofrecer mayores garantías a quienes participan de su estudio. En esta línea, el proceso aquí aludido se encontró marcado por una vinculación directa y hasta íntima entre el equipo de investigación y los fotógrafos, a quienes se informó - a través de dos formularios de consentimiento- del contexto y sentido de esta experiencia de fotografía colaborativa, además de asegurarles confidencialidad y anonimato. La entrega de las cámaras no estuvo sujeta a algún compromiso o indicación con respecto al contenido de las tomas fotográficas, sino solo a concertar dos reuniones posteriores: una, a fin de recoger las cámaras y proceder a su revelado en un laboratorio y, la otra, para entregar las fotografías a sus autores y conversar acerca de ellas. Instándoles a pormenorizar cada una en cuanto a contenido, locación, actores presentes e importancia del registro, se les invitó a participar activamente en su progresiva selección y titulación, esto último orientado a la realización de las exposiciones que en cada una de las ciudades del estudio se llevó a cabo. ${ }^{3}$

No obstante estas consideraciones, el ejercicio de reconocimiento y de producción fotográfica compartida implicó diversos niveles de tensión que conviene reseñar. En primer término, la naturaleza participativa de la creación de estas tomas fotográficas no puede evadir el irresoluto debate sobre la autoría. Aun cuando hubo un especial cuidado en que la producción del dato perteneciera en su mayor medida al fotógrafo, reconociéndoles los créditos por sus imágenes y respetando al máximo su decisión editorial en la selección que luego fue presentada en las exposiciones fotográficas, los registros fueron custodiados, analizados y comunicados por los investigadores. En este punto, resulta complejo controlar que el protagonismo de los fotógrafos no sea eclipsado por la autoridad etnográfica, pues las fotografías y sus testimonios asociados comienzan a circular de la manera en que lo hace el conocimiento antropológico: a partir de decisiones editoriales y epistemológicas del antropólogo. Se vuelve así escurridizo el componente participativo que primó en el momento etnográfico del trabajo, y comienzan a circular en canales en los que se desvanece la presencia de los fotógrafos, siempre bajo el peligro de retornar a su clásica condición de informantes (Restrepo 51).

3 A fin de compartir el trabajo y producir un segundo conjunto de materiales relativo a la recepción de las imágenes, el proyecto llevó a cabo siete exposiciones entre octubre de 2016 y marzo de 2017, tres en la ciudad de Santiago, dos en Arica, una en Paysandú y otras dos en Montevideo, con un total de veinte días de exhibición. 
Por otra parte, la privacidad y anonimato se revistieron de complejidades que forman parte del terreno compartido de la investigación antropológica. Mientras el estudio busca reconocer e incentivar la condición de sujetos, particulares e historizados, de los fotógrafos, simultáneamente hubo que desplegar una serie de herramientas editoriales que terminan por desconectar a la persona individualizada de sus creaciones, por ejemplo, cubriendo o difuminando sus rostros en algunas presentaciones con el propósito de resguardar su privacidad por desconocimiento de lo que permitía o no el consentimiento, lo que en una población históricamente invisibilizada emerge como otra forma de violencia o suplantación. De cualquier forma, y de acuerdo a los compromisos estipulados en los formularios aludidos, se protegieron las identidades de los fotógrafos mediante el uso de seudónimos o iniciales, tanto en comunicaciones académicas como en el montaje de las exposiciones.

Con todo, con aciertos y limitaciones, los resguardos y procedimientos éticos apuntaron a construir una relación de confianza entre investigadores y fotógrafos, relación que no acaba en el formulario o en la serie de encuentros llevados a cabo. En este marco, el dispositivo fotográfico permitió alentar una discursividad participativa que tiende a corregir la verticalidad de otros instrumentos de investigación, como el lenguaje cerrado del cuestionario o la cuantía y directividad de la encuesta. Las posibilidades que convocan las imágenes requieren esta intervención minimizada de los investigadores.

Puesto así, a continuación se presenta una pequeña selección de las fotografías que se produjeron en el marco de este ejercicio. Al ser imágenes capturadas por sus propios protagonistas, no son el producto de un esteticismo impuesto desde afuera, ni responden a los preceptos institucionales y normativos con los que se ha representado la situación de calle. No se trata de afirmar que los documentos aquí examinados constituyen imágenes más auténticas o verdaderas de la situación de calle, ni de asegurar que las consideraciones tomadas por el estudio constituyen una garantía de cierta mirada imparcial liberada, finalmente, del dominocentrismo. Más bien, se sostiene que la producción compartida de estas imágenes ofrece un margen más amplio para la emergencia de esas voces marginadas, en parte porque estas no están subordinadas a las expectativas de un público receptor que busca encontrar en las imágenes la representación hegemónica de la miseria. En las diversas vertientes y grados de la "porno-miseria", el proceso de producción de imágenes se encuentra regido por un espectro de representaciones prefiguradas acerca del otro subordinado, que tamizan la realidad en función de un filtro miserabilista. Como demuestran las imágenes a continuación, los fotógrafos de este estudio realizan tomas fotográficas que no responden a aquella agenda de representación exotizada de la pobreza, y que en algunos casos hasta les hizo confesar que se sintieron como harían los artistas. Yendo aún más lejos, y a la luz de la discusión propuesta, se plantea que es posible pensar estas imágenes en clave de contravisualidad; es decir, como dispositivo político que introduce una ruptura en aquello que ha sido definido como legítimamente visible. 
FIGURA 1

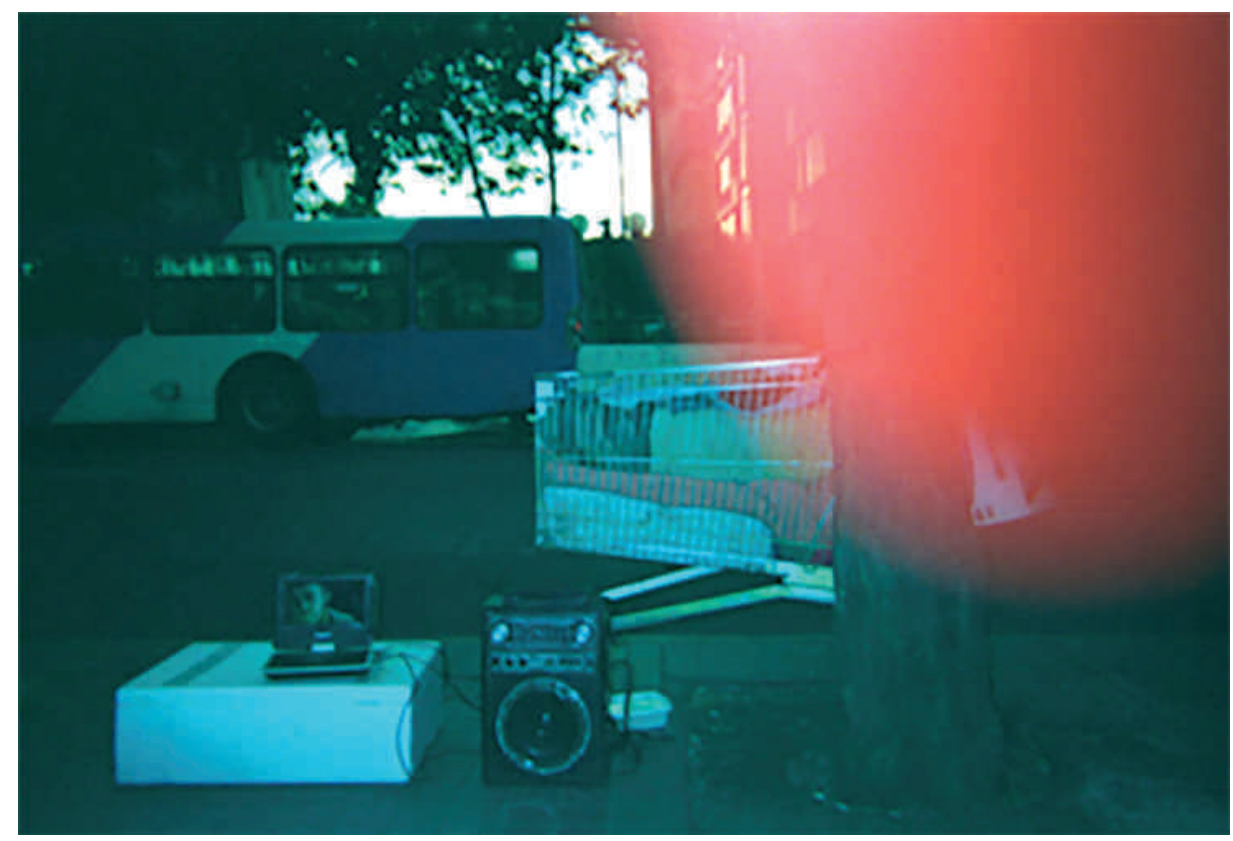

Sin título (E. H., Santiago, 11.02.16).

\section{FIGURA 2}

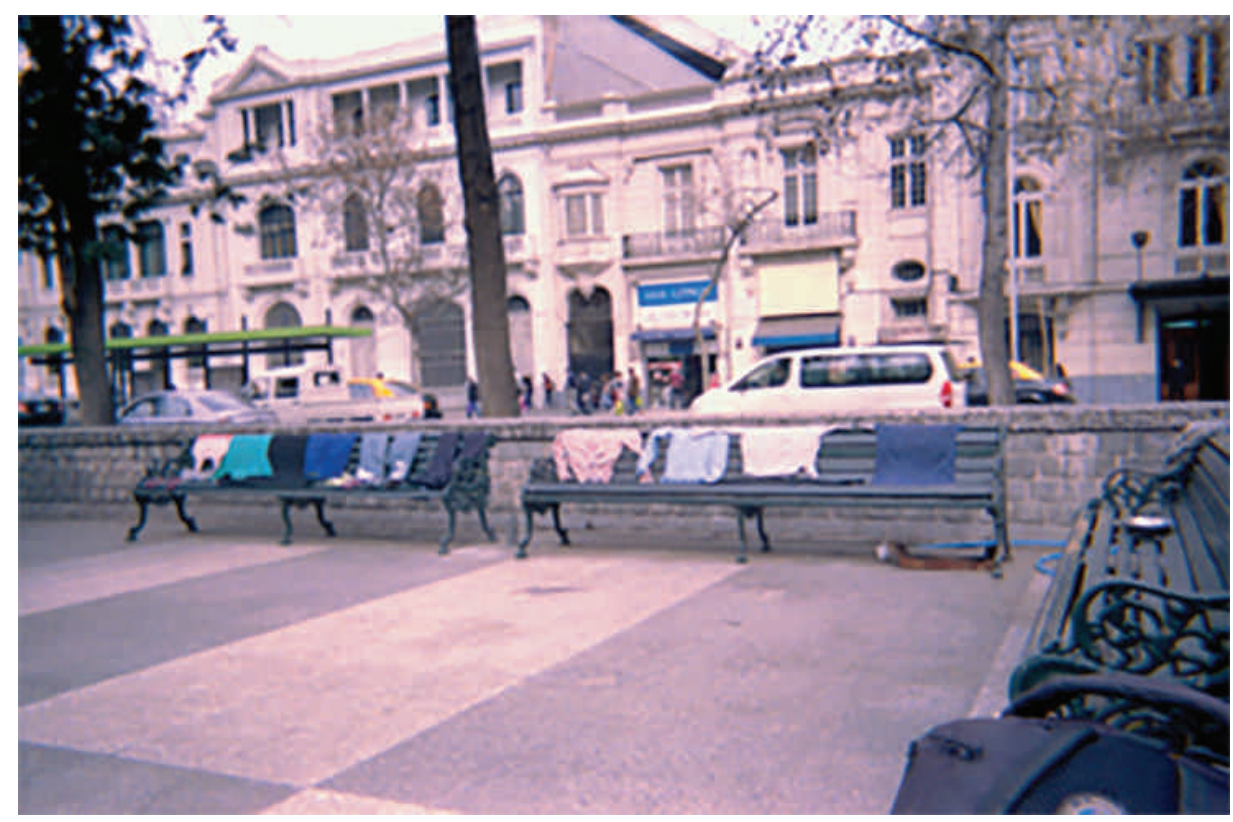

Sin título (M. B., Santiago, 28.08.15). 


\section{FIGURA 3}

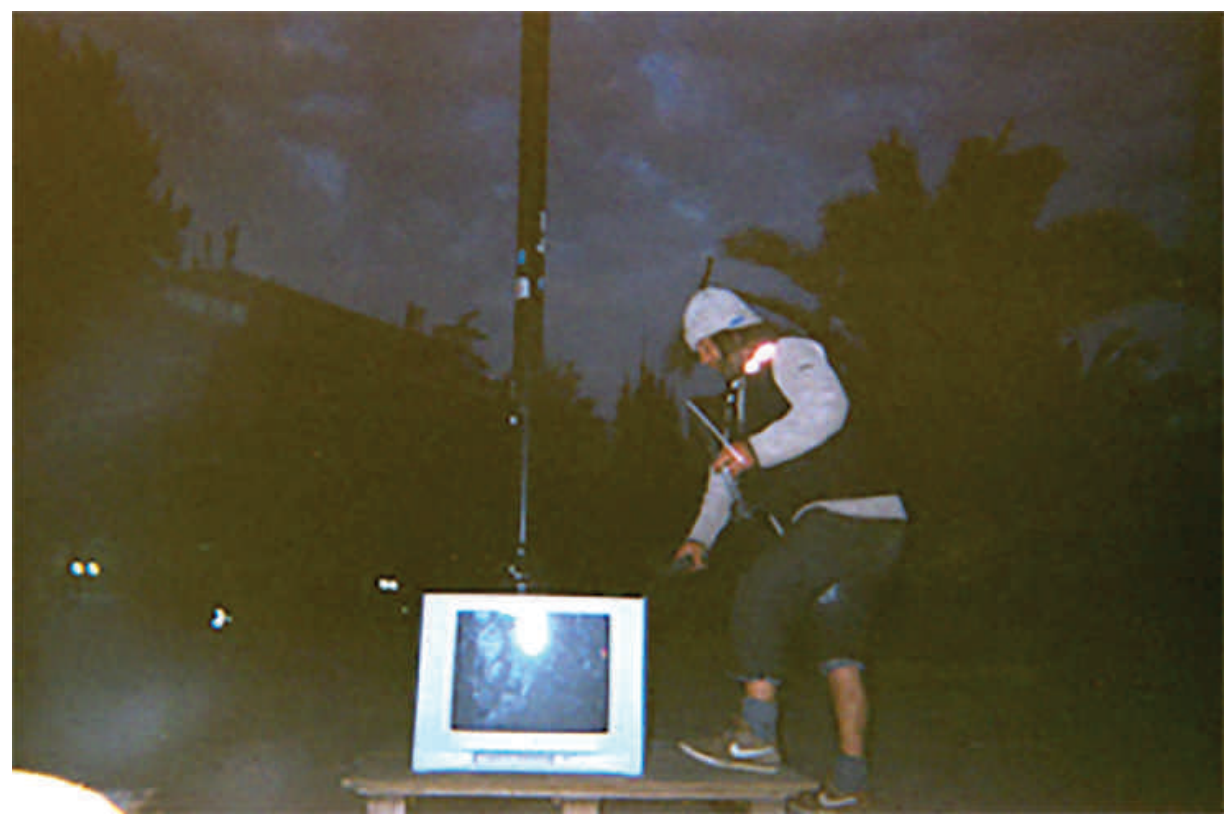

Sin título (F. B., Santiago, 12.09.15).

Uno: sobre una caja de poliestireno expandido o plumavit, un poderoso sistema de sonido amplifica las emisiones de la pantalla de un computador, con la avenida principal de la ciudad como telón de fondo [fig. 1]. Dos: un conjunto de prendas de ropa se airean de forma distendida en el tendedero improvisado que conforman dos escaños públicos [fig. 2]. Tres: es de noche, y un hombre ajusta la antena de su televisor, instalado sobre un palé o palet de madera que hace las veces de mesa de centro [fig. 3]. Cuatro: entre los relieves de cemento de un parque, se ha instalado una parrilla que ha marcado con hollín las paredes. Sobre ella, se aprecia una batería de ollas y sartenes desgastadas por el uso [fig. 4]. En las fotografías mencionadas - de E. H., M. B., F. B. y otra vez de M. B._, la imagen parece restituir a esta población un elemento que suele estar reservado al ámbito del domicilio: la capacidad de habitar (apropiarse de; instalarse en) un territorio. Las actividades domésticas y cotidianas, como tender la ropa, cocinar o ver televisión, se hacen un lugar en medio de una ciudad que ha marcado como ilegítima la visibilidad de estas prácticas. En cada una de ellas, estos gestos de ocupación efectiva y de uso reiterado imprimen un sello de permanencia y estabilidad a una serie de prácticas que el discurso oficial solo admite como erradicables. El hollín de muchas fogatas sobre aquella cocina hechiza, o la estructura compleja y difícilmente portable del home theather de la calle permiten observar que se trata de prácticas persistentes en el tiempo, y no soluciones transitorias gestadas en el marco de una situación excepcional. Como acredita el fracaso relativo de los 
FIGURA 4

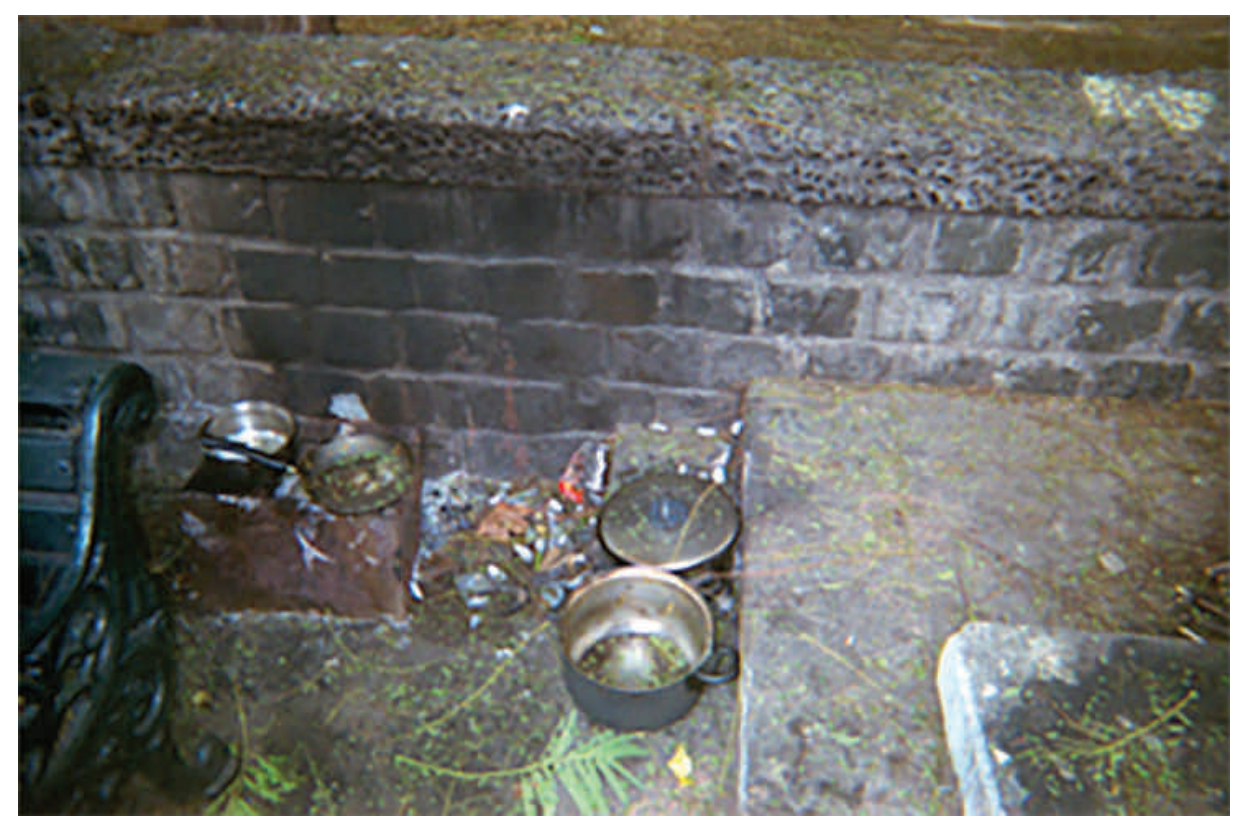

Sin título (M. B., Santiago, 28.08.15).

programas estatales, que en último término aspiran a la erradicación de la situación de calle, este estilo de vida no puede entenderse solo como un producto mecánico de la necesidad: hay también elección, adaptación y creatividad en él, y estos indicios de la permanencia y la apropiación apuntan en este sentido. Estas imágenes presentan usos no permitidos - y por lo tanto, invisibles - de la vía pública, disputando en aquel gesto las representaciones hegemónicas de la ciudad y de los modos de habitar en ella.

Cinco: en contrapicado, se observa un paisaje urbano con sus edificios, sus semáforos, su cielo soleado. Un marco impreciso y una veladura celeste borronea la imagen [fig. 5]. Seis: gracias a esta fotografía, se entiende aquello que captó la imagen anterior. Un hombre dentro de una tienda de campaña sonríe a la cámara. Las piernas de una mujer se hacen a un lado, para ceder protagonismo al sujeto del retrato [fig. 6]. Esta dupla de fotografías de L. G. y J. I. reestructuran en diversos niveles los imaginarios de la vida en situación de calle. En primer término, ofrecen evidencia de que estas formas de habitar la calle no son necesariamente experiencias solitarias y ermitañas, sino que admiten la vida en pareja y el establecimiento de vínculos sociales perdurables y significativos. Como se apuntó anteriormente, la desafiliación ha sido uno de los rasgos que se asume y proyecta sobre esta población como condición imperativa. Por otro lado, las fotografías develan también otros elementos que se conciben exclusivos del domicilio, como el despliegue de la privacidad. Las fotografías aquí analizadas permiten acceder a una suerte de adentro, marcado por la veladura de la tienda y por 


\section{FIGURA 5}

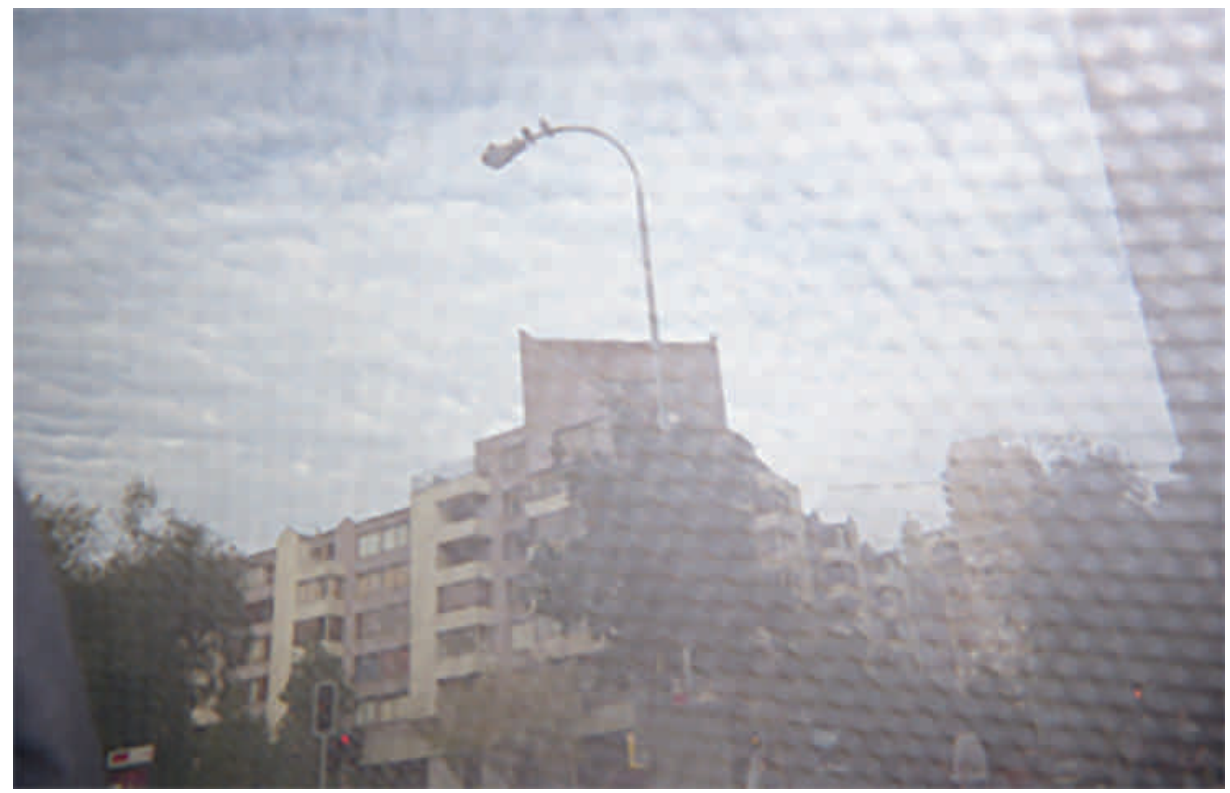

Sin título (L. G., Santiago, 04.07.16)

\section{FIGURA 6}

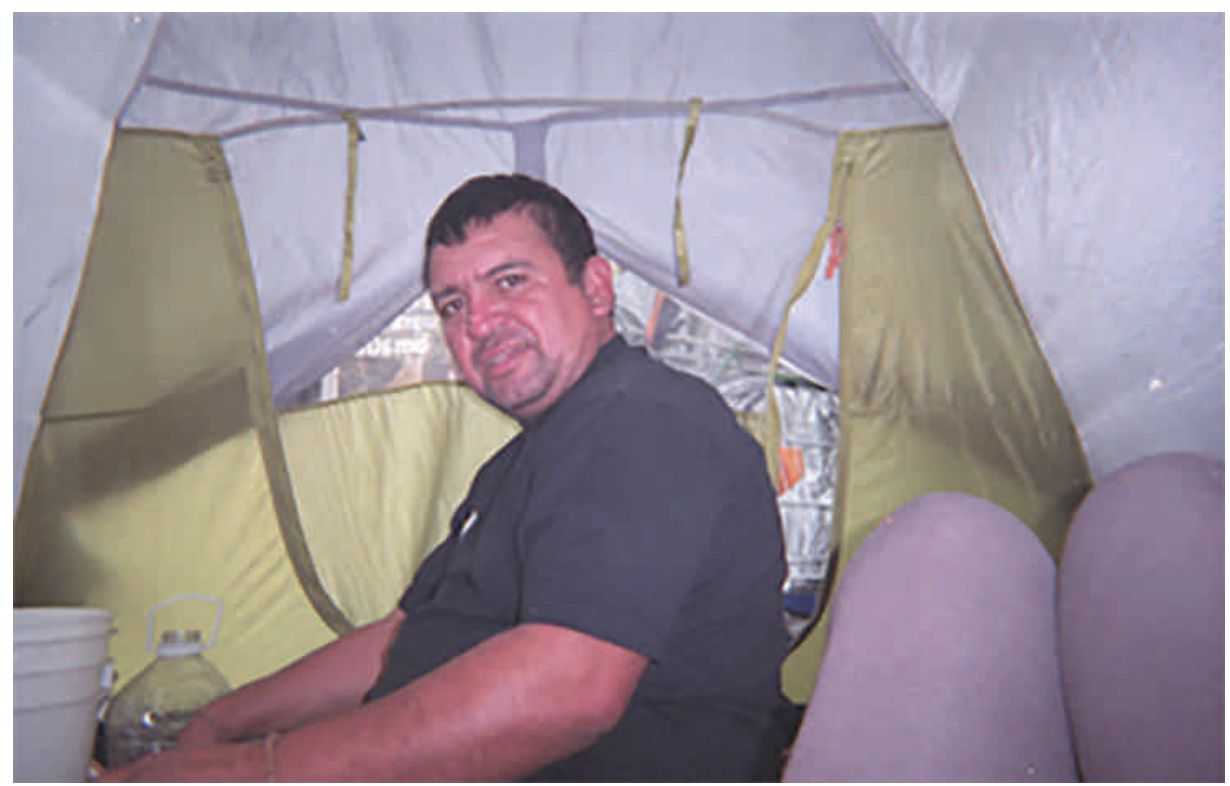

Sin título (J. I., Santiago, 04.07.16) 
FIGURA 7

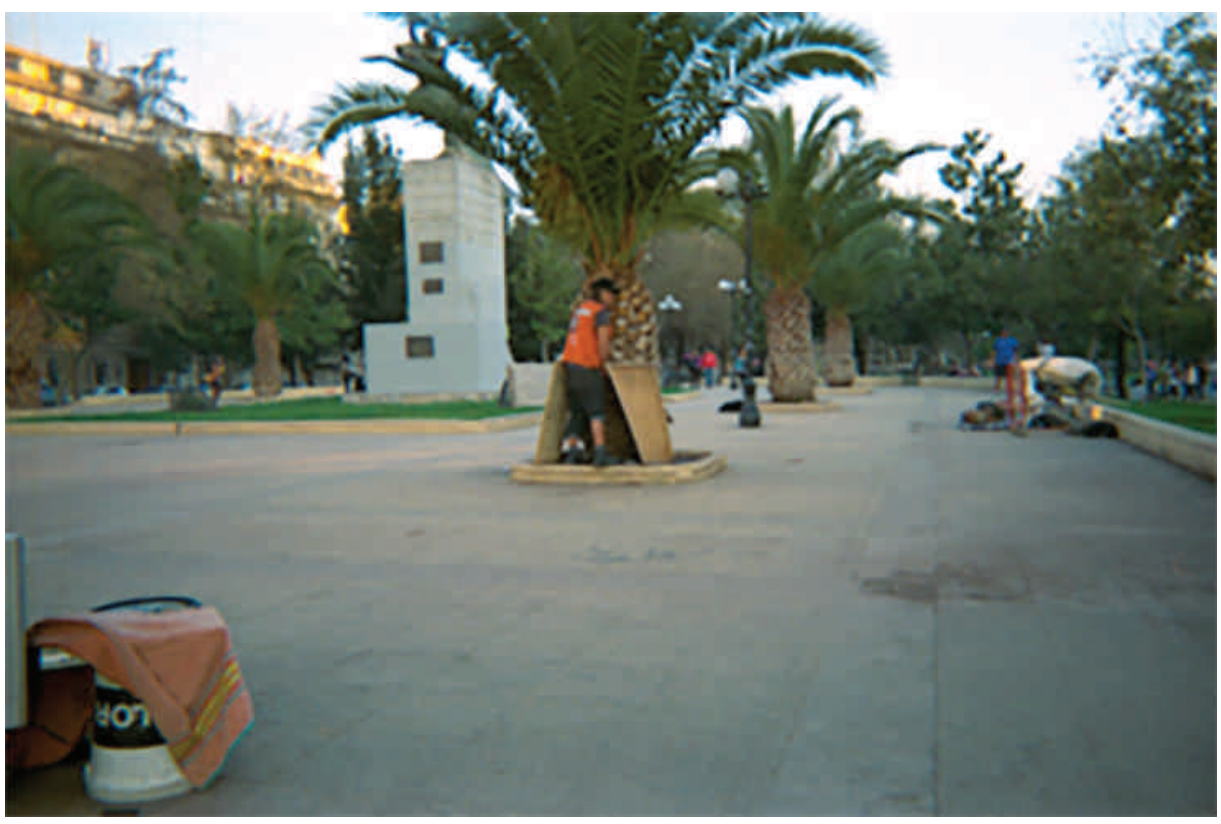

Sin título (F. B., Santiago, 12.09.15).

el gesto de complicidad de los cuerpos. Ese espacio infranqueable de la intimidad, noción vinculada a la confianza que ofrece esa trama de sociabilidad que compone la familia y la casa, es también concebido como un privilegio del domicilio. Es más, en la historia de exclusiones que ha construido a las personas en situación de calle como sujetos marginados de la vida propiamente social, tal vez este sentido de lo privado constituye incluso un rasgo "hominizador": a diferencia de los animales, la humanidad propia se alcanza ejerciendo con privacidad - léase dignidad - aquellas funciones biológicas que nos atan a la naturaleza. Así, dormir, comer, orinar, desprovistas del pudor de lo íntimo, parecen empujar a quienes habitan la calle hacia los confines de lo humano. Estas fotografías construyen su derecho de mirada desafiando el supuesto que les niega la posibilidad de intimidad: es contravisual, en aquella medida, en tanto permite pensar otras formas de percibir la realidad y reorganizar sus categorías.

Siete: fuera de conjunto, pero completando la serie desde una otra vereda, el acto de orinar por parte de un hombre que mira hacia atrás al medio de una explanada en un parque de la ciudad [fig. 7] queda registrado en lo público tal como podría ocurrir puertas adentro del domicilio. Afuera esta vez, su escenificación al costado de una palmera y en medio de dos planchas de madera aglomerada que confieren una incierta privacidad señalan su cotidiano acto como algo que igualmente se lleva a efecto en la calle, como adaptación creativa, y tal como hace la población domiciliada cuando el imperio de la fisiología así lo demanda. Con el mismo derecho, y con la misma 
condición humana, esta fotografía tiene la virtud de aproximar dos poblaciones separadas por la puerta del domicilio, o del baño, pero que siguen siendo equivalentes en ello, y en el humor que está detrás del acto de arrancarla de la intimidad con que se ha revestido socialmente su abordaje.

Las imágenes examinadas permiten observar cómo el espacio público se tiñe de experiencias privadas. Privadas, porque como se aprecia en el segundo grupo de fotografías, están llenas de complicidad íntima, pero también porque, como se ve en el primero de ellas, se trata de experiencias singulares, de apropiación y de construcción de un habitar cotidiano que permanece. Esta disrupción de lo público, que es aquello que constituye el patrimonio de todos y se construye en un intersticio común, puede convertirse en proyecto contravisual: en un documento crítico que rompe el escenario urbano de lo legítimamente perceptible. Estas fotografías ofrecen una nueva clave de lectura sobre los universos simbólicos de la vida en la calle: en cuanto registros del diario vivir, las fotografías no solo muestran dificultades, sino la búsqueda de soluciones y también el goce que comprehensivamente les ha sido mezquinado. Aparece la familia y su compañía, la contemplación del paisaje, la fiesta y la risa; elementos que niegan que el domicilio sea el único elemento posibilitador de la vida social. Y que, en el caso de lo segundo, signándosele históricamente como malentretenimiento (Araya 19), también se le ha interpretado como un tipo de subordinación sensual, y no ascética, dada por la negativa del peonaje a hacer abandono del goce y la libertad, especialmente la del juego (Bengoa 26-27). ¿Fotografías de la miseria? No, pues los fotógrafos invitan al espectador a permitirse observar puertas adentro de la calle, $\mathrm{y}$ en ese espacio, como en cualquier otro, las fórmulas reduccionistas de comprender la realidad se tornan rápidamente obsoletas.

\section{A modo de cierre}

Compartiendo con Panchoaga la necesidad de subsanar nuestros analfabetismos visuales (citado en Martínez 210), este artículo ha querido exponer una experiencia investigativa en el doble registro de algunos de sus resultados gráficos y de la reflexión que suscitan. El esfuerzo resulta, a la vez, pretencioso - pues se trata de la selección de una pequeña parte de los materiales producidos - y sugerente - dado el potencial que como representación, denotativa o connotativa, igualmente posee (Rabadán y Contreras 144-145). Para concluir estas reflexiones, quedan todavía algunas ideas por puntualizar.

Uno, las imágenes no son la realidad. Como recorte de ella, constituyen un continuo y poroso encadenado de intereses que la van seleccionando: los de los fotógrafos que las tomaron; pero también los del equipo de investigación que fue sobre sus huellas y que, a pesar del esfuerzo coautoral, no pudo evitar escribir sobre ellas. Lo mismo el lector, que tampoco puede escapar al ojo a través del cual observa las imágenes y lee esta afirmación. 
Dos, como propuesta contravisual, igualmente cumple y deja de cumplir lo que se propone. Los materiales faltantes plantean una duda acerca de qué podría decirse y cuánto de ello estaría signado por el marco teórico e ideológico de quienes no pueden despojarse de su autoridad etnográfica. Empero, el intento de difuminar dicha autoridad a partir del entramado metodológico, ético y epistemológico que se ha expuesto, tampoco resulta inocuo: no se habla por, sino con, las imágenes y las personas que las tomaron. El horizonte al que se accede no es ni puede ser el de la conmiseración que - movilizada por su pretensión humanitaria- lo que ha hecho, precisa y contradictoriamente, es despojarla.

Tres, en tanto esfuerzo por restituir un derecho de mirada, se observa lo que se nos ha mostrado y se guía su lectura a partir de lo que se dice. En ello también una representación, se avanza hacia una caracterización del fenómeno que - trascendiendo el peso de los domiciliocentrismos - habla de estabilidad, vínculo, descanso o goce. Al hacerlo, muestra además los muchos vínculos con el domicilio que, literal y metafóricamente, son negados: el jontiter de la calle (en alusión al home theather) por ejemplo, pero también el baño de Carlitos (en alusión al acto de orinar sin las paredes de un baño), aproximan material y simbólicamente estas fronteras.

La arbitrariedad, sin embargo, con que tradicionalmente se han abordado los confines de lo marginal, no puede no interpelar a los autores de este artículo. La situación de calle, ciertamente, se encuentra atravesada por una desigualdad innegable: ¿Quiere decir ello que se celebra su injusticia por discutir la arquitectura con la que se ha construido? ¿Se es cómplice de la carencia por observar, por ejemplo, el amor de pareja o la fiesta irrestricta que también se celebra bajo techo? Sin respuesta ante tales preguntas, la seguridad de que ahí hay tanta humanidad como en los contextos del domicilio, impide esa otra complicidad; la del miserabilismo que acá se ha discutido.

\section{Referencias}

Araya, Alejandra. Ociosos, vagabundos y malentretenidos en Chile colonial. Santiago, Chile, DIBAM, LOM, Centro de Investigaciones Diego Barros Arana, 1999.

Voces de La Guerrero. Dirigida por Adrián Arce, Diego Rivera y Antonio Zirión, Homo Videns. ORG, 2004. DVD.

Arcos, Andrea. Retrato y representación social de la situación de calle. Un acercamiento a la vida de cuatro personas de la ciudad de Santiago. Tesis Universidad Bolivariana, 2013.

Bachiller, Santiago. "El aislamiento social como supuesto articulador de las teorías sobre la exclusión y el sinhogarismo: críticas y aportes etnográficos". Cultura - Hombre - Sociedad CUHSO 19.1 (2010): 9-21.

Bahr, Howard. Skid Row: an Introduction to Disaffiliation. New York, Oxford University Press, 1973. 
Bengoa, José. El poder y la subordinación: acerca del origen rural del poder y la subordinación en Chile. Santiago, Chile, Sur, 1988.

Benjamin, Walter. El autor como productor. Madrid, Taurus, 1975.

Bermúdez, Bertha. El hombre es, los de la calle tienen, uno debe... (re) Construcción de identidades masculinas en situación de calle. Tesis Universidad de Chile, 2009.

Buente, Wayne, y Luz Quiroga. 2014. "Assessing the Role of Computers, Mobile Phones, and Social Network Sites on Homeless Social Capital and Social Relationships". Proyecto de investigación, University of Hawaii.

Bufarini, Mariel. "Las personas sin hogar en Rosario. Consideraciones sobre los usos del espacio público urbano”. Cultura - Hombre - Sociedad CUHSO 19.1 (2010): 67-74.

Camejo, Soledad, Luigi Della Mea, Sofía Monetti, Daniel Pérez, Natalia Pintado y Romina Santos. "Situación de calle y Ley de faltas. Continuidades y rupturas en las políticas de abordaje a las personas en situación de calle, a partir de la aprobación e implementación de la Ley de Faltas". XIII Jornadas de Investigación de la Facultad de Ciencias Sociales. Universidad de la República, Montevideo. 15 - 17 sep. 2014. Ponencia.

Didi-Huberman, Georges. Cuando las imágenes toman posición. Madrid, Antonio Machado, 2008.

Espada, Arcadi. "La necesidad de la imagen: entrevista con Susan Sontag”. Letras Libres [Edición España] 31 (2004): s. p.

Fabian, Johannes. Time and the Other: How Anthropology Makes his Object. New York, Columbia University Press, 1983.

Foster, Hal. "El artista como etnógrafo". El retorno de lo real: La vanguardia a fines de siglo. Ed. Hal Foster. Madrid, Akal, 2001, pp. 175-207.

González, Lya. "La ruta de la cuchara: itinerarios de la caridad en Santiago". Vagabundos y andantes. Etnografías de Santiago, Valparaíso y Temuco. Eds. Francisca Márquez y Patricio Toledo. Santiago, Chile, Universidad Academia de Humanismo Cristiano, 2010, pp. 153-171.

Grignon, Claude y Jean-Claude Passeron. Lo culto y lo popular: miserabilismo y populismo en sociología y literatura. Buenos Aires, Nueva Visión, 1989.

Grinschpun, Alejandra y Manuel Bendersky. Otra mirada: Buenos Aires fotografiada por los chicos que viven en sus calles. Buenos Aires, Asociación Civil Los Chicos de la calle, 2005.

Hodgetts, Darrin, Andrea Hodgetts y Alan Radley. "Life in the Shadow of the Media: Imaging Street Homelessness in London”. European Journal of Cultural Studies 9.4 (2006): 497-516.

Leiva, Gonzalo. Sergio Larraín: Biografía / estética / fotografía. Santiago, Chile, Metales Pesados, 2012.

Levi-Strauss, David. “The Documentary Debate: Aesthetic or Anaesthetic”. Writing the Essay, Art in the World, the World through Art. Eds. Darlene Forrest, Randy Martin y Pat Hoy. Boston, McGraw-Hill, 1992. 147-151. 
Marcazzolo, Leo. “'Se llevaron al Anticristo! Municipalidad lo internó en una clínica siquiátrica". The Clinic [Santiago, Chile]. 15 jun. 2006: 6-7.

Martínez, Santiago. "Habitares cotidianos. Fotografía, etnografía y pensamiento. Conversación con Jorge Panchoaga”. Antípoda. Revista de Antropología y Arqueología 25 (2016): 208-214.

Melleiro, Marta, y Dulce María Rosa Gualda. "La fotovoz como estrategia para la recolección de datos en una investigación etnográfica”. Ciencia y Enfermería 11.1 (2005): 51-57.

Merton, Robert. Teoría social y estructura social (4 estudios). Santiago, Chile, Andrés Bello, 1960.

Miller, Cynthia. "Images from the Streets: Art for Social Change from the Homelessness Photography Project”. Social Justice 33.2 (2006): 122-134.

Mirzoeff, Nicholas. "El derecho a mirar". IC, Revista Científica de Información y Comunicación 13 (2016): 29-65.

Morales, Eduardo y Sergio Rojas. Relocalización socioespacial de la pobreza. Política estatal y presión popular, 1979-1985. Santiago, Chile, Programa FLACSO, 1986.

Ospina, Luis y Carlos Mayolo. ¿Qué es la porno-miseria? Texto presentado con motivo de la première de la película Agarrando Pueblo en el cine Action République. París, 1977.

Piña, Leonardo. Calle y casa. La situación de calle como fenómeno de frontera. Puerto Montt, avances para una comprensión desde sus actores. Tesis Universidad de Tarapacá y Universidad Católica del Norte, 2013.

Rabadán, Ángel y Paloma Contreras. "La Fotografía Participativa en el contexto socio-educativo con adolescentes". Comunicación y Hombre 10 (2014): 143-156.

Radley, Alan, Darrin Hodgetts y Andrea Cullen. "Visualizing Homelessness: a Study in Photography and Estrangement". Journal of Community and Applied Social Psychology 15.4 (2005): 273-295.

Rancière, Jacques. La división de lo sensible: Estética y política. Salamanca, Centro de Arte de Salamanca, 2002.

-_. Sobre políticas estéticas. Barcelona, Museu d’Art Contemporani de Barcelona, 2005.

-_. El desacuerdo. Buenos Aires, Nueva Visión, 2007.

- - "El teatro de imágenes". La política de las imágenes. Santiago de Chile, Metales Pesados, 2008, pp. 69-89.

Restrepo, Eduardo. Etnografía: alcances, técnicas y éticas. Bogotá, Envión editores, 2016.

Rice, Eric, Diana Ray y Seth Kurzban. "Homeless but Connected: the Role of Heterogeneous Social Network Ties and Social Networking Technology in the Mental Health Outcomes of Street-living Adolescents". Community Mental Health Journal 48.6 (2012): 692-698. Web. 22 mar. 2018.

Romaní, Oriol. “Antropología de la marginación. Una cierta incertidumbre”. Ensayos de antropología cultural. Eds. Joan Prat y Ángel Martínez. Barcelona, Ariel, 1996, pp. 303-318. 
Sontag, Susan. Ante el dolor de los demás. Ciudad de México, Alfaguara, 2014. Spivak, Gayatri. “¿Puede hablar el subalterno?”. Orbis Tertius 3.6 (1998): 175-235. Web. 22 de mar. 2018

Tylor, Edward. Cultura primitiva. Madrid, Ayuso, 2001.

Enviado: 10 abril 2018

Aceptado: 14 enero 2019 